\title{
The Nauplius Larva of Anelasma squalicola (Lovén).
}

\author{
By \\ Winifred E. Frost, M.Sc., \\ Department of Oceanography, University, Liverpool.
}

With 4 Figures in the Text.

The Cirripede Anelasma squalicola (Lovén) is parasitic on the smooth dogfish, Etmopterus spinax (Linnæus). These fish, which are caught at a depth of about 150-180 fathoms, were brought to the University of Liverpool as material for a chemical investigation by Professor Heilbronn and his colleagues. On finding that some of the fish were thus parasitised, Professor J. Johnstone and myself made a study of the general morphology of Anelasma (3).

During this research our interest was aroused by the presence of developing eggs and embryos contained in the "mantle cavity" of mature specimens, but no trace could be found of a completely developed larva ; thus no mention of it was made in the account of Anelasma.

Since the publication of the paper, however, Mr. C. F. Hickling has obtained specimens of the larvæ taken from adult parasites captured off the Flannan Islands, in the Western Hebrides region, in 270 fathoms of water. Owing to the peculiar structure of the adult organism, it was thought that the present description of the larval form would prove of interest.

There are very few references to the nauplius of Anelasma; the oldest one is the paper by Koren and Danielssen in a Swedish publication of 1848 (1), and the account given there is summarised by Hoek in his paper on "Die Cirripidien" published in Nordisches Plankton (2).

Groom, in his well-known and detailed memoir on the "Early Development of the Cirripedia," makes no mention of this particular larva ; and although Darwin in his great monograph describes the adult animal, he has no reference to the early form.

While at sea, Mr. Hickling obtained the larvæ by dissecting out the " ovigerous lamellæ" from the "mantle cavity"; he then hatched the eggs from these structures in a jar of sea-water and was thus able to make some interesting observations on the living animals.

When first hatched he noticed the nauplii moving actively by jerking movements of the antennæ. Later, the larvæ were even more vigorous, using now both legs and antennæ in a haphazard way in order to effect 
movement, and rolling over and over as they swam. The limbs themselves appeared to be very small in relation to the size of the body and, because of the uncoordinated way in which they were used, the nauplii made little progress. The form of the appendages and their functioning made a strong contrast with Balanus nauplii, where the appendages are comparatively large and their movements are rapid.

This contrast possibly may be correlated with the fact that these larvæ of Anelasma had been developed from eggs definitely removed for that purpose from the "mantle cavity" of the adult. Mr. Hickling suggests that under "natural" conditions the larvæ would still have been in the shelter of that " cavity" at this stage and would not be free-swimming at all (this may account for their peculiar movement).

After the above observations had been made, Mr. Hickling preserved nauplii of one and four days old and forwarded them to me. It is on these specimens that the following description is based.

\section{General Appearance.}

The uniformity of general appearance which characterises the Cirripede larvæ makes it easy, even from a cursory glance, to identify this nauplius as belonging to this class of Crustacea; its specific characters are made out with closer study : it is small, being about $665 \mathrm{~mm}$. in length and about $437 \mathrm{~mm}$. at its widest part; the length agrees with that given by Koren and Danielssen, but they give a much smaller measurement for the breadth; the animal is just visible to the naked eye. It is opaque and colourless and has a general vacuolated appearance, which is due to the oil-laden cells.

The greater part of the body is covered by a dorsal, segmented carapace and this is produced at its antero-lateral extremities into two processes, the fronto-lateral horns so typical of all Cirripede nauplii. Each "horn " has a slight bifurcation at its distal end; this really marks the opening of a minute passage which leads down into the "fronto-lateral gland"; two processes, known as "fronto-lateral filaments," usually present in Barnacle larvæ are absent. No trace whatever could be found of that very typical structure, the nauplius eye. This fact is pointed out by Hoek, though he speaks of a small star-like speck which is to be seen on the dorsal surface; this may, however, be only a pigment spot.

The main part of the body just described passes posteriorly into a fivesegmented spine, $.115 \mathrm{~mm}$. in length, whose chitinous covering is a continuation of the carapace. On looking down on the ventral surface of the animal a relatively large proboscis, or labrum, is seen bearing two small processes at its tip. It lies in such a way that it points slightly backwards and downwards in relation to the rest of the body; in a lateral 
view it is not seen at all. In other nauplii the mouth would be found beneath this proboscis, but it has not been seen in Anelasma.

\section{The Appendages.}

The appendages are best seen in a ventral view of the animal (Fig. 1). Laterally the distal ends are alone visible, and it is only possible, from the dorsal surface, to see the bristles attached to them. The appendages
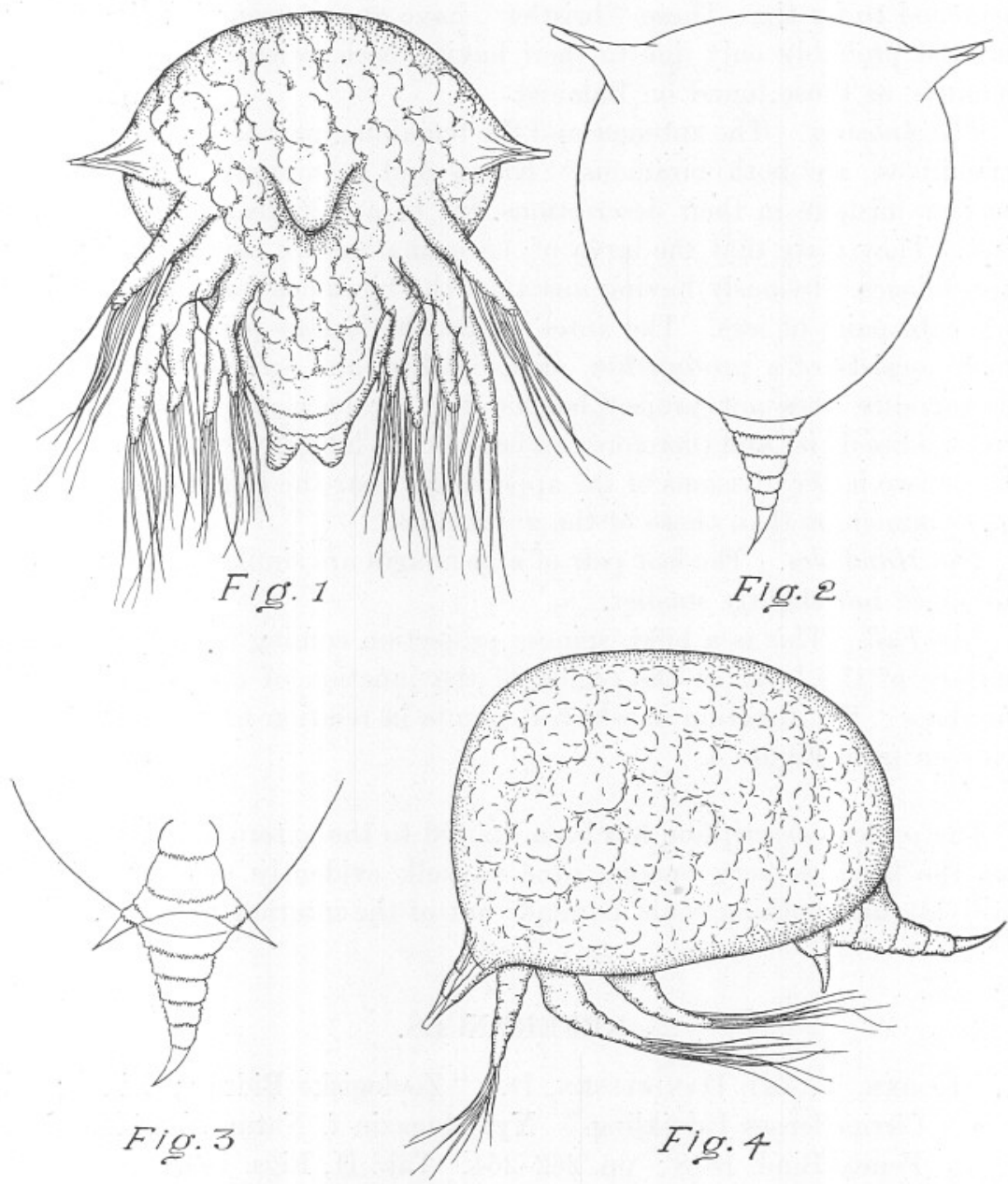

Fras. 1-4.-The nauplius of Anelasma squalicola.

(1) A nearly ventral view; (2) dorsal view ; (3) the tail parts-ventral view (4) lateral view. The four drawings are all made from different larvæ.

Dimensions.-The nauplii are very nearly the same in length. The length of the one represented in Fig. 2 is $0.665 \mathrm{~mm}$.; its breadth is $0.44 \mathrm{~mm}$. The length of the caudal spine is $0.115 \mathrm{~mm}$. 
of most nauplii are segmented; those of Anelasma have curious "creasings" suggestive of incipient jointing, but definite segmentation seems absent. There are the three pairs of appendages typical of the nauplius.

The Antennules. The first pair of appendages which project forward, arise quite near, and slightly posterior to the "fronto-lateral horns." They are uniramous and beset with "bristles" or setæ, one of which comes off close to the tip of the appendage, whilst the remainder are attached to its tip. These "bristles" have an apparent jointing; this is most probably only due to their having been twisted; they are not plumose as those found on Balanus.

The Antennax. The antennæ and the remaining pair of appendages, the mandibles, are both biramous. Koren and Danielssen have made a curious mistake in their descriptions due to a misinterpretation of this fact. They state that the larva of Anelasma has six pairs of uniramous appendages, obviously having mistaken the biramous formation for four separate pairs of legs. The antennæ are the largest pair of limbs, and each consists of a protopodite, an exopodite, and an endopodite. The protopodite does not project beyond the carapace, the exopodite and endopodite do so, and therefore can be seen in a lateral view of the animal. These two latter divisions of the appendages bear the bristles, longer and more numerous than those of the antennules.

The Mandibles. The last pair of appendages are similar in form to the antennæ, but slightly smaller.

The Tail. This is a bifid, spinose projection coming from the ventral surface of the body at the region of the junction of caudal spine and carapace; the direction in which it points in relation to the former can be seen from Figure 4 .

The present description has been limited to the external features only, for the larva is very opaque (due to yolk evidently not yet entirely utilised), and nothing could be made out of the internal anatomy.

\section{REFERENCES.}

1. Koren, I., and Danielssen, D. "Zoologiske Bidrag; Bidrag Til Cirripedernes Udvikling." Nyt Magazin f. Naturvidensskaberne. Femte Bind, 1848; pp. 262-264. Tab. II, Figs. 1-3.

2. Hoek, P. P. C. "Die Cirripedien"; Nordisches Plankton. Bd. 4. p. 304.1909.

3. Johnstone, J., And Frost, W. E. 35th Annual Rept. Lancashire Sea-Fish-Laby. for 1926. (1927.) 